\title{
Comparative Pharmacokinetics of the Orally Administered Sub-lethal Doses of Miconazole Nitrate in Labeo rohita
}

\author{
Mukta Singh, Himadri Saha and Ratan Kumar Saha* \\ Department of Aquatic Health and Environment, College of Fisheries, \\ CAU, Lembucherra, Agartala, Tripura-799210, India \\ *Corresponding author
}

\begin{tabular}{|l|}
\hline K e y w o r d s \\
miconazole nitrate, \\
Labeo rohita, \\
Pharmacokinetics, \\
Elimination \\
\hline Article Info \\
\hline $\begin{array}{l}\text { Accepted: } \\
\text { 20 November } 2020 \\
\text { Available Online: } \\
\text { 10 December } 2020\end{array}$ \\
\hline
\end{tabular}

\section{A B S T R A C T}

\section{Introduction}

Oomycetes are some of the most damaging pathogens responsible for diseases in freshwater fish; in particular, Saprolegnia is an aquatic oomycete negatively affecting the aquaculture industry (van West, 2006). Saprolegniasis is the disease caused by the etiologic agent Saprolegnia characterized by white or gray patches of mycelium growing on the epidermis of fish and enters the blood vascular system in the case of severe infections. This disease condition is predominantly a result of secondary infection incited by the compromised immune system of fish in illness or adverse environmental conditions (Sarowar et al., 2013). The respiratory and osmoregulatory functions of 
the fish are severely affected during the gill invasion of Saprolegnia inciting acute respiratory failure leading to death (Sarowar et al., 2013).

In the earlier days, Saprolegnia infections were treated successfully with the chemical dye malachite green (Olah and Farkas, 1978; Srivastava and Srivastava, 1978; Alderman, 1985) until this was banned globally in 2002 for its known carcinogenic, mutagenic, and teratogenic properties ( $\mathrm{Hu}$ et al., 2019; Van West, 2006; Stammati et al., 2005; Srivastava et al., 2004). Besides this, other chemical compounds such as formaldehyde, hydrogen peroxide, sodium chloride (Rach et al., 2005; Barnes et al., 2003), copper sulphate (Straus et al., 2009), bronopol (Pottinger and Day, 1999) and ozone (Forneris et al., 2003) were also utilized to eradicate the fungal pathogen but none were as effective as malachite green and the environmental impacts of these chemicals are also apprehensive (Song et al., 2020; Pottinger and Day 1999). The unregulated and extensive use of these chemicals in aquaculture farms gave rise to some serious concerns like the development of the resistant strains of fungus and their potential harm to human health (Phillips et al., 2008; Stammati et al., 2005). To address these situations and to help farmers encountering the deadly winter kill pathogen, the need arises to develop an alternate safe and cost-effective treatment for Saprolegnia for preventing significant economic loss in the aquaculture industry.

To counter and control these pathogens, miconazole nitrate (MCZ), a synthetic broadspectrum imidazole antifungal agent (Godefroi et al., 1969; Van Custem and Thiepont, 1972) that has been used for nearly 40 years to treat infections effectively and safely in human and veterinary animals (Vazquez and Sobel, 2012) was utilized in fish (Singh et al., 2018a). It was observed and reported that the orally administered miconazole in guinea-pigs, was more potent and promptly effective against fungus than any other established antifungal like nystatin, amphotericin B and pimaricin (VanCutsem and Thienpont, 1972). MCZ was reported as a very effective and promising drug to be used as therapeutic (Singh et al., 2018a) as well as a prophylactic agent (Singh et al., 2018b) against Saprolegnia in rohu fingerlings. The discoveries correlating novel mode of action through multifarious clinical trials confirm the pharmacological efficacy of the drug against diverse fungal strains (Barasch and Griffin, 2008) with a wide safety margin in various animal species (Robert A. and Fromtling, 1988; Van Custem and Thiepont, 1972; Moriello, et al., 2017)

The preferences of administering the antifungal drug and dosing regimen are among the factors which have to be stated by a fisheries clinician, though at times the drug concentration at the site of infection is widely influenced by the pharmacokinetic variability and may contribute to the treatment failure. The drug exposure with the lack of proper pharmacokinetic data can sometimes even exceed the probable extent resulting in toxicity. The antifungal drugs display the discrete variation in the drug plasma concentrations due to their inconsistency in the absorption and elimination rate. An understanding of the pharmacokinetics of these drugs has been observed to be a crucial factor in optimizing drug dosage and administration. The most convenient mode of detecting drug exposures for the effective medication in fisheries is the monitoring of drug concentration in fish plasma. This study was undertaken to comprehend the pharmacokinetics of MCZ in L. rohita after single oral administration of three sub-lethal doses (Singh et al., 2018a) for better insight into the drug action in the fish. 


\section{Materials and Methods}

\section{Chemicals}

Miconazole nitrate (white powder form, purity > 98\%) was obtained from Sigma Aldrich Chemical Co. (USA). HPLC-grade acetonitrile and water were purchased from Himedia Laboratories Supplies (UK). Sodium acetate was purchased from Sigma Aldrich Chemical Co. (USA). All other chemicals used were of HPLC grade.

The stock solution was prepared at a concentration of $1000 \mathrm{mg} \mathrm{l}^{-1} \mathrm{MCZ}$ in acetonitrile and stored at $-20^{\circ} \mathrm{C}$ until further need. Six reference samples containing $0.5,1$, 5, 10, 15, 20, $25 \mu \mathrm{g} \mathrm{ml}{ }^{-1}$ of MCZ were prepared by diluting this stock solution with drug-free pooled fish plasma. These samples were used to assess accuracy and precision. For routine use of the assay, a single-point working standard plasma containing $\mathrm{MCZ}$ at $1.0 \mu \mathrm{g} \mathrm{ml}^{-1}$ in drug-free plasma was prepared and stored in $1 \mathrm{ml}$ aliquots at $-20^{\circ} \mathrm{C}$.

\section{Chromatographic conditions}

The HPLC system employed for the study was a Merck-Hitachi Lachrom system (Tokyo, Japan) equipped with a quaternary pump L-7100, an integral degasser, an interface D-7000 and a UV detector module L-7400,. For data acquisition and processing, the chromatography software ChromQuest 5.0 was used. A manual injector system (Rheodyne, Cotati, CA, USA) equipped with a $20 \mu \mathrm{l}$ sample loop and $100 \mu \mathrm{l}$ syringe (Hamilton, Microliter 710, Bonaduz, Switzerland) was used. The HPLC column was a ZORBAX Eclipse XDB-C18 $(4.6 \mathrm{~mm} \times 150 \mathrm{~mm}, 5 \mu \mathrm{m}$ particle size), Agilent Technologies. The chromatographic separation was performed following Hosotsubo (1988) using a mobile phase consisting of $80: 20(\mathrm{v} / \mathrm{v})$ mixture of acetonitrile and $0.05 \mathrm{M}$ sodium acetate buffer $(\mathrm{pH} \mathrm{7.4)}$ in a flow rate of $1.5 \mathrm{ml} / \mathrm{min}$ which produces a column pressure of about 70 bars (1,000 p.s.i.). Solvents were filtered through $0.45 \mu \mathrm{m}$ pore Nylon filter membrane before use. The column was maintained at $25^{\circ} \mathrm{C}$ and an injection volume of $10 \mu \mathrm{l}$ was used. The detection was performed at $232 \mathrm{~nm}$.

\section{Calibration curves and recovery studies}

The calibration curves for MCZ were obtained by reference samples with standard solutions of fish plasma to yield $0.5,1,5,10$, $15,20,25 \mu \mathrm{g} \mathrm{ml}^{-1}$ of MCZ. Triplicate samples were used. The recovery rates were determined by comparing the results of the analysis of the reference samples with those of standard solutions. The linearity of the standard curves for MCZ in fish plasma was tested using peak-height measurements. Precision is the measurement of the closeness of individual data sets or agreement among a set of results. It was conducted using six replicates of MCZ standard solutions. The percent of relative standard deviation (\% RSD) for peak responses was calculated. Limit of detection (LOD) and limit of quantification (LOQ) were calculated based on the standard deviation of response and slope of the mean analytical curve and were expressed as a signal to noise ratio $3: 1$ and 10:1 for LOD and LOQ, respectively ( $\mathrm{ICH}$, 2005).

\section{Experimental fish}

Healthy L. rohita $(24.2 \pm 1.5 \mathrm{~g})$ was collected from the farm of the College of Fisheries, CAU, Lembucherra. Acclimatization of collected fingerlings was done for about 20 days in circular fibre reinforced plastics (FRP) tanks (Plasto Craft, Mumbai) of 5001 capacity and was fed with a routine amount of pelleted feed twice daily. Proper aeration was provided and feeding was done adlibitum. A 
completely randomized design (CRD) was followed throughout the experiment. The different quality criteria of the water were checked daily. The temperature of the experimental tanks was maintained at 27.5 ${ }^{\circ} \mathrm{C}-28.5{ }^{\circ} \mathrm{C}, \mathrm{pH}$ was about 7.5 , and the ammonia and dissolved $\mathrm{O}_{2}$ levels were about $0.1 \mathrm{mg} \mathrm{l}^{-1}$ and $>7$ ppm respectively.

\section{Dosing and Sampling}

The fish were divided randomly into three treatment groups and a control group in triplicate and were acclimatized with the experimental control feed. A total of five hundred and forty (540) acclimatized rohu fish were distributed uniformly in 12 FRP tanks. The fish were famished for $24 \mathrm{~h}$ premedicated feed administration, for immediate feed consumption and to avoid leaching of the MCZ from the feeds. Four iso-nitrogenous (35.18-35.99\% crude protein) and iso-caloric (357-365 kcal $100 \mathrm{~g}^{-1}$ ) diets were prepared (Table 1) as per treatment doses control- 0.0 $\mathrm{mg} \mathrm{kgBW}^{-1}$, T1- $6.30 \mathrm{mg} \mathrm{kgBW}^{-1}$, T2- 12.61 $\mathrm{mg} \mathrm{kgBW}^{-1}$ and T3- $25.22 \mathrm{mg} \mathrm{kgBW}^{-1}$ (Singh et al., 2018a).

Fish received one dose of MCZ feed as per the above-mentioned doses as $1 \%$ of their body weight and were witnessed for 5 minutes for probable regurgitation. The feeding percentage was selected for the avoidance of residual experimental feeds as well as to maintain the certainly required dose of application. The feed intake was observed to be instant and the entire experimental diet was consumed by the fish within $5 \mathrm{~min}$ of feeding. Samples of blood were taken under clove oil anaesthesia from the caudal vein of three-four fish each at $0.25,0.5,1,4,6,8,12$, 24, 48, 96, 120 and $240 \mathrm{~h}$ post-drug administration. Blood was stored on ice and the plasma samples were prepared by centrifugation at $3500 \mathrm{~g}$ for $5 \mathrm{~min}$, then transferred immediately to sterile tubes and preserved at $-20^{\circ} \mathrm{C}$ until further analysis using HPLC.

\section{Sample preparation}

A $100 \mu \mathrm{l}$ volume of plasma standard or sample was pipette into a 2-mL microcentrifuge tube, and protein precipitation was initiated by the addition of an equal volume of acetonitrile. The stopped tube was vortexed for $30 \mathrm{sec}$, kept standing for $5 \mathrm{~min}$ at room temperature and then centrifuged at $12,000 \mathrm{~g}$ for $2 \mathrm{~min}$. Finally, a $10 \mu \mathrm{l}$ aliquot of the supernatant was injected into the HPLC system.

\section{Pharmacokinetic analysis}

The determination of pharmacokinetic parameters of MCZ was done by the noncompartmental pharmacokinetic model based on the statistical moment theory. The area under the concentration-time curve (AUC) was determined using the trapezoidal method. The elimination rate constant $(\beta)$ was the slope of the linear regression equation on $\log$ transferred MCZ concentration ( $\ln \mathrm{C}$ ) against time, and the elimination half-life $\left(\mathrm{t}_{1 / 2 \beta}\right)$ was calculated from the equation $t_{1 / 2}=0.693 / \beta$ for each treatment. After oral administration, the peak concentration $\left(\mathrm{C}_{\max }\right)$ and time to reach $\mathrm{C}_{\max }\left(\mathrm{T}_{\max }\right)$, half-value duration (HVD) and mean residence time (MRT) were directly estimated using the pharmacokinetic software Kinetica program (5.0; Thermo Scientific Corporation, USA).

\section{Statistical analysis}

Statistical analysis was done using SPSS-16.0 (SPSS Inc., Chicago IL, USA). Results are presented as mean \pm standard error. Comparisons of mean were done using oneway analysis of variance (ANOVA) and Duncan's test. Probability levels of 0.05 were used to find out the significance in all cases. 


\section{Results and Discussion}

\section{Detection limit and recovery percentage}

Using the described conditions, miconazole was found to have a retention time of 8.175 min. A linear relationship was shown through the calibration curve with a range of 0.5 to $25 \mu \mathrm{g} \mathrm{ml}{ }^{-1}$, with an elevated correlation coefficient indicating linearity $\left(\mathrm{R}^{2}=0.995\right)$ in fish plasma (Fig.1). The recovery rate for MCZ from fish plasma was also calculated and is shown in Table 2. The extraction procedures were validated and showed good recovery of MCZ. The recovery of MCZ varied from $88.70 \%$ to $99.03 \%$ for fish plasma. The precision of these recovery studies varied from $0.34-1.97 \%$. The limit of detection (LOD) and limit of quantification (LOQ) of MCZ in plasma was $0.032 \mu \mathrm{g} \mathrm{ml}^{-1}$ and $0.109 \mu \mathrm{g} \mathrm{ml}{ }^{-1}$ respectively. No interference was seen during analysis, when calibrating the curves, or when performing recovery studies.

\section{Pharmacokinetics}

The mean concentrations of MCZ versus time in plasma of $L$. rohita after administration are shown in Fig. 2. MCZ Plasma concentration of lowest dose in first treatment (T1) reached $1.45 \mu \mathrm{g} \mathrm{ml}^{-1}$ at $1 \mathrm{~h}$ and the maximum plasma concentration $\left(5.35 \mu \mathrm{g} \mathrm{ml}^{-1}\right)$ was reached at 6 $\mathrm{h}$ after feeding. After this, the drug level declined rapidly and reached $0.07 \mu \mathrm{g} \mathrm{ml}^{-1}$ close to the limit of detection at $240 \mathrm{~h}$. Plasma concentration of second dose treatment (T2) reached $2.31 \mu \mathrm{g} \mathrm{ml}^{-1}$ at $1 \mathrm{~h}$ and the maximum plasma concentration $\left(9.44 \mu \mathrm{g} \mathrm{ml}^{-1}\right)$ was reached at $6 \mathrm{~h}$ after feeding. After this, the drug level declined rapidly and reached 0.54 $\mu \mathrm{g} \mathrm{ml} l^{-1}$ at $240 \mathrm{~h}$. Plasma concentration of third dose treatment (T3) reached $8.32 \mu \mathrm{g}$ $\mathrm{ml}^{-1}$ at $1 \mathrm{~h}$ and the maximum plasma concentration $\left(20.28 \mu \mathrm{g} \mathrm{ml}^{-1}\right)$ was reached at $8 \mathrm{~h}$ after feeding. After this, the drug concentration declined rapidly and reached $1.02 \mu \mathrm{g} \mathrm{ml}^{-1}$ at $240 \mathrm{~h}$. $\mathrm{T}_{\max }$ of all the doses varied from 6 to $8 \mathrm{~h}$ and with the increase in dose, the $T_{\max }$ also gets delayed. However, the pharmacokinetic analysis showed that the $\mathrm{C}_{\max }$ in the study varied from 5.35 to $20.86 \mu \mathrm{g}$ $\mathrm{ml}^{-1}$ and the concentration increases with each time interval of sampling till the highest peak in plasma was obtained. The total area under the curve (AUC) was varied from 263.11 to $1048.99 \mu \mathrm{g}^{*} \mathrm{~h} \mathrm{ml}^{-1}$ and subsequently, the mean residence time also varied between $52 \pm 0.13$ to $98 \pm 0.23 \mathrm{~h}$. The $R$ square $\left(\mathrm{R}^{2}\right.$ value) from the pharmacokinetic model used by the Kinetica 5.0 varied from 0.87 to 0.98 . The statistical analysis showed that the parameters like $\mathrm{T}_{\max }, \mathrm{C}_{\max }, \mathrm{t}_{1 / 2 \beta}$, AUC and MRT of all the experimental groups fed with MCZ based feed are significantly $(p<0.05)$ different from each other. The HVD value of MCZ in plasma of rohu was observed to be $5.53 \pm 0.02 \mathrm{~h}, 8.53 \pm 0.07 \mathrm{~h}$ and $36.71 \pm 0.05 \mathrm{~h}$ respectively for all three doses. The elimination of MCZ in rohu after three sub-lethal oral dosing was rapid and the halflife $\left(t_{1 / 2 \beta}\right)$ was estimated to be $30 \mathrm{~h}, 71 \mathrm{~h}$ and $77 \mathrm{~h}$ respectively in plasma. All the pharmacokinetic parameters are shown in Table 3.

Despite the immense interest in $L$. rohita as characterized by its good flesh quality, high market demand and acceptability by consumers, the kinetics and dosing study of any potent antifungal drug have not been very well established. Therefore, the present work was conducted to assess the MCZ pharmacokinetic profile of three sub-lethal doses (Singh et al., 2018a) in L. rohita after a one-time feed administration in the fish. The stock and the reference solutions had separation and good peak symmetry as obtained by using the mobile phase of 80: 20 $(\mathrm{v} / \mathrm{v})$ mixture of acetonitrile and $0.05 \mathrm{M}$ sodium acetate buffer. The retention time of MCZ was found to be 8.175 min. DeZan et 
al., (2009) during the method validation of MCZ has observed the retention time of 8.3 min on using a mobile phase of water, methanol, and acetonitrile for $15 \mathrm{~min}$ which was extremely stable among injections. The serum MCZ analysis using a mobile phase of 85:15 methanol and aqueous 0.05 M ammonium phosphate buffer gave a lower retention time of $6.05 \mathrm{~min}$ at $230 \mathrm{~nm} \mathrm{UV}$ detection (Puranajoti et al., 1999). Some reports have differences in the retention time of MCZ resulting from slight variations in the composition of the mobile phase, wavelength and the flow rate of the mobile phase (Hermawan et al., 2017).

Table.1 Formulation of three sublethal doses of experimental diets (100g) containing MCZ in the required quantity for the pharmacokinetic study

\begin{tabular}{lcccc}
\hline Ingredients & Control diet & $\begin{array}{c}\text { Quantity (in g) } \\
\text { Diet T1 }\end{array}$ & $\begin{array}{c}\text { Diet T2 } \\
(\mathbf{1 2 . 6 1} \mathbf{~ m g}\end{array}$ & $\begin{array}{c}\text { Diet T3 } \\
(\mathbf{2 5 . 2 2} \mathbf{~ m g ~ k g} \\
\left.\mathbf{~ B W}^{\mathbf{- 1}}\right)\end{array}$ \\
\hline Casein & & 16.0 & 16.0 & 16.0 \\
Gelatin & 16.0 & 8.0 & 8.0 & 8.0 \\
Dextrin & 8.0 & 30.0 & 30.0 & 30.0 \\
Fish meal & 30.0 & 16.0 & 16.0 & 16.0 \\
CMC & 16.0 & 2.0 & 2.0 & 2.0 \\
Veg oil & 2.0 & 4.5 & 4.5 & 4.5 \\
Cod liver oil & 4.5 & 4.5 & 4.5 & 4.5 \\
Vit-min mixture* & 4.5 & 6.0 & 6.0 & 6.0 \\
BHT & 6.0 & 0.2 & 0.2 & 0.2 \\
Cellulose & 0.2 & 12.74 & 12.67 & 12.55 \\
Drug & 12.80 & 0.06 & 0.12 & 0.25 \\
\hline
\end{tabular}

*Composition of vitamin-mineral premix (PREEMIX PLUS) (quantity2.5 $\mathrm{kg}^{-1}$ ): Vitamin A, 5500000 IU; Vitamin $\mathrm{D}_{3}, 1100000 \mathrm{IU}$; Vitamin $\mathrm{B}_{2}, 2000 \mathrm{mg}$; Vitamin E, $750 \mathrm{mg}$; Vitamin K, $1000 \mathrm{mg}$; Vitamin $\mathrm{B}_{6}, 1000 \mathrm{mg}$; Vitamin $\mathrm{B}_{12}, 6 \mathrm{mcg}$; Calcium Pantothenate, $2500 \mathrm{mg}$; Nicotinamide, $10 \mathrm{~g}$; Choline Chloride, $150 \mathrm{~g}$; Mn, 27,000 mg; I, 1000 mg; Fe, 7500 mg; Zn, 5000 mg; Cu, 2000 mg; Co, 450mg; L- lysine, 10 g; DL- Methionine, 10 g; Selenium, 50 ppm.

Table.2 Recovery of MCZ from the plasma of L. rohita with the described HPLC conditions $(\mathrm{n}=3)$

\begin{tabular}{ccc}
\hline MCZ added $\left(\boldsymbol{\mu} \mathbf{~ m l}^{-1}\right)$ & $\begin{array}{c}\text { MCZ found (mean } \pm \\
\text { SE) }\left(\boldsymbol{\mu} \mathbf{~ m l}^{-1}\right)\end{array}$ & $\begin{array}{c}\text { Recovery }(\text { mean } \pm \\
\text { SE) }(\boldsymbol{\%})\end{array}$ \\
\hline $\mathbf{0 . 5}$ & $0.46 \pm 0.01$ & $92.03 \pm 2.71$ \\
\hline $\mathbf{1 . 0}$ & $0.93 \pm 0.02$ & $93.10 \pm 2.98$ \\
\hline $\mathbf{1 . 5}$ & $1.32 \pm 0.01$ & $88.70 \pm 0.91$ \\
\hline $\mathbf{2 . 0}$ & $1.87 \pm 0.04$ & $93.50 \pm 1.78$ \\
\hline $\mathbf{3 . 0}$ & $2.89 \pm 0.02$ & $96.33 \pm 2.54$ \\
\hline $\mathbf{4 . 0}$ & $3.96 \pm 0.02$ & $99.03 \pm 0.88$ \\
\hline $\mathbf{5 . 0}$ & $4.88 \pm 0.01$ & $97.60 \pm 1.98$ \\
\hline \multicolumn{3}{c}{ mean \pm SE } \\
\hline
\end{tabular}


Table.3 Pharmacokinetic parameters for MCZ were calculated in plasma of L. rohita after oral administration with three different sublethal doses at different sampling hours. Control: fish fed with a basal diet without MCZ. T1, T2 and T3: fish fed with diets containing $\mathrm{MCZ}$ at the inclusion levels of $6.30 \mathrm{mg} \mathrm{kgBW}^{-1}, 12.61 \mathrm{mg} \mathrm{kgBW}^{-1}$ and $25.22 \mathrm{mg} \mathrm{kgBW}^{-1}$ respectively

\begin{tabular}{|c|c|c|c|c|c|c|c|c|}
\hline Parameters & $\mathbf{T}_{\max }$ & $\mathbf{C}_{\max }$ & HVD & $\mathbf{t}_{1 / 2 \beta}$ & $\mathbf{A U C}$ & MRT & AUMC & $\mathbf{R}^{2}$ \\
\hline Unit & (h) & $\left(\mu \mathrm{g} \mathrm{ml}^{-1}\right)$ & (h) & (h) & $\left(\mu \mathrm{g}^{*} \mathrm{~h} \mathrm{ml} \mathrm{l}^{-1}\right)$ & (h) & $\left(\mu \mathrm{g}^{*} \mathrm{~h}^{2} \mathrm{ml}^{-1}\right)$ & \\
\hline Control & N/A ${ }^{*}$ & N/A ${ }^{*}$ & N/A ${ }^{*}$ & N/A ${ }^{*}$ & N/A ${ }^{*}$ & N/A ${ }^{*}$ & N/A & N/A* \\
\hline T1 & $6 \pm 0^{a}$ & $5.35 \pm 0.29^{\mathrm{a}}$ & $5.53 \pm 0.02^{\mathrm{a}}$ & $30 \pm 0.51^{\mathrm{a}}$ & $263.11 \pm 9.92^{\mathrm{a}}$ & $52 \pm 0.62^{\mathrm{a}}$ & $13943 \pm 21.98^{\mathrm{a}}$ & $0.87^{\mathrm{a}}$ \\
\hline $\mathbf{T} 2$ & $6 \pm 0^{\mathrm{a}}$ & $9.44 \pm 0.30^{\mathrm{b}}$ & $8.53 \pm 0.07^{b}$ & $71 \pm 0.92^{\mathrm{b}}$ & $472.96 \pm 13.76^{\mathrm{b}}$ & $66 \pm 0.73^{b}$ & $31458 \pm 32.09^{b}$ & $0.91^{\mathrm{b}}$ \\
\hline T3 & $8 \pm 0^{b}$ & $20.28 \pm 0.48^{\mathrm{c}}$ & $36.71 \pm 0.05^{c}$ & $77 \pm 0.83^{c}$ & $1049.99 \pm 18.03^{\mathrm{c}}$ & $98 \pm 0.23^{\mathrm{c}}$ & $66653 \pm 27.80^{c}$ & $0.98^{\mathrm{c}}$ \\
\hline
\end{tabular}

N/A: not available

Data are presented as mean \pm SE. $a, b$ and c indicate statistically significant difference $(p<0.05)$ when compared with the control group. Data is Tmax, Time of maximum plasma concentration; Cmax, Calculated maximum plasma concentration; HVD, Half value duration; $t_{1 / 2}$, Elimination half-life; AUC, Area under the concentration-time curve; MRT, mean residence time; AUMC, Area under the first moment of the concentration-time curve. 
Fig.1 Mean analytical curve obtained from MCZ standard and reference solutions ( 0.5 to $25.0 \mu \mathrm{g}$ $\mathrm{ml}^{-1}$ ) using the HPLC chromatogram system

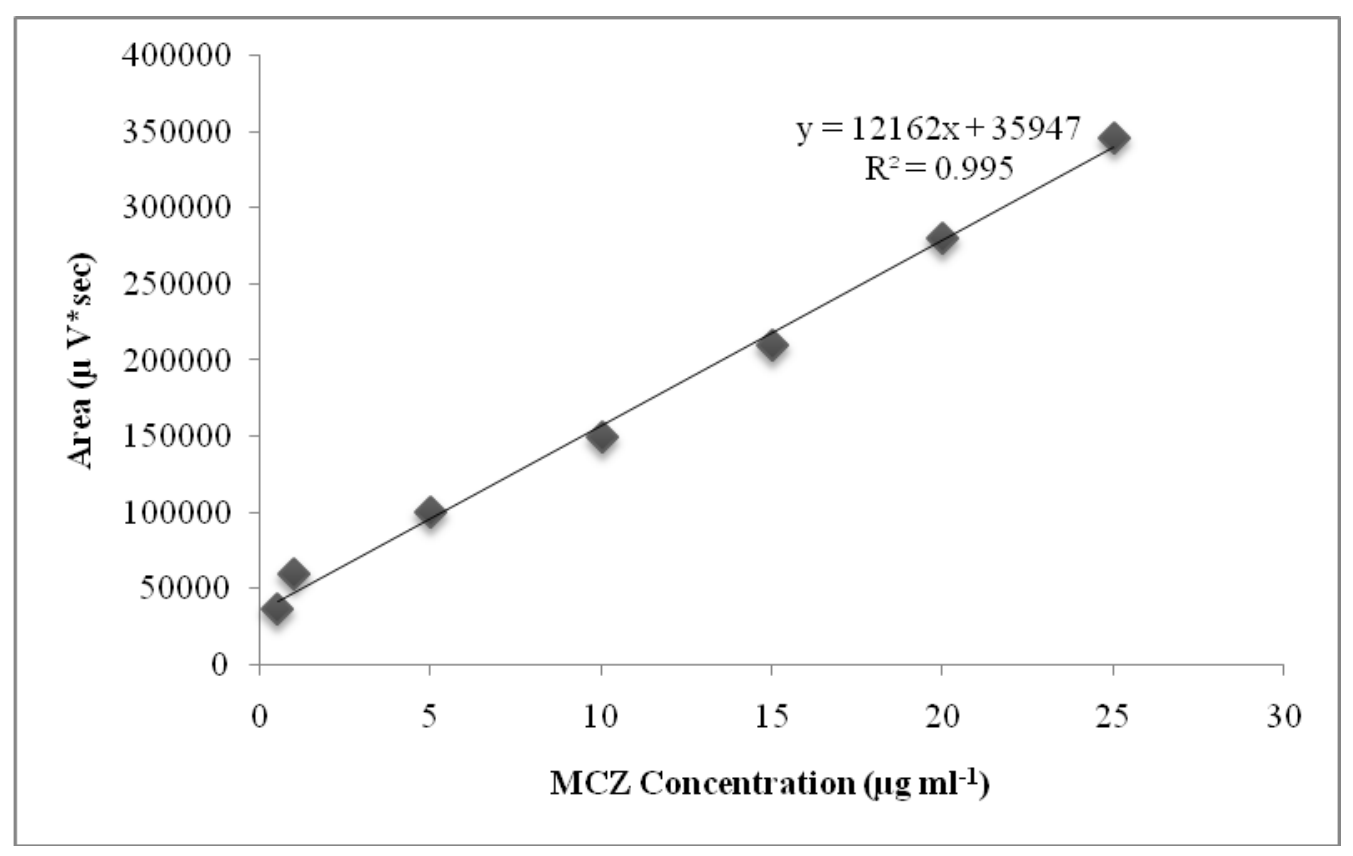

Fig.2 MCZ levels (mean \pm SD) determined in the plasma of L. rohita after single oral administration with three different sub-lethal doses at different sampling hours. Control: fish fed with a basal diet without MCZ. T1, T2 and T3: fish fed with diets containing MCZ at the inclusion levels of $6.30 \mathrm{mg} \mathrm{kgBW}^{-1}, 12.61 \mathrm{mg} \mathrm{kgBW}^{-1}$ and $25.22 \mathrm{mg} \mathrm{kgBW}^{-1}$, respectively.

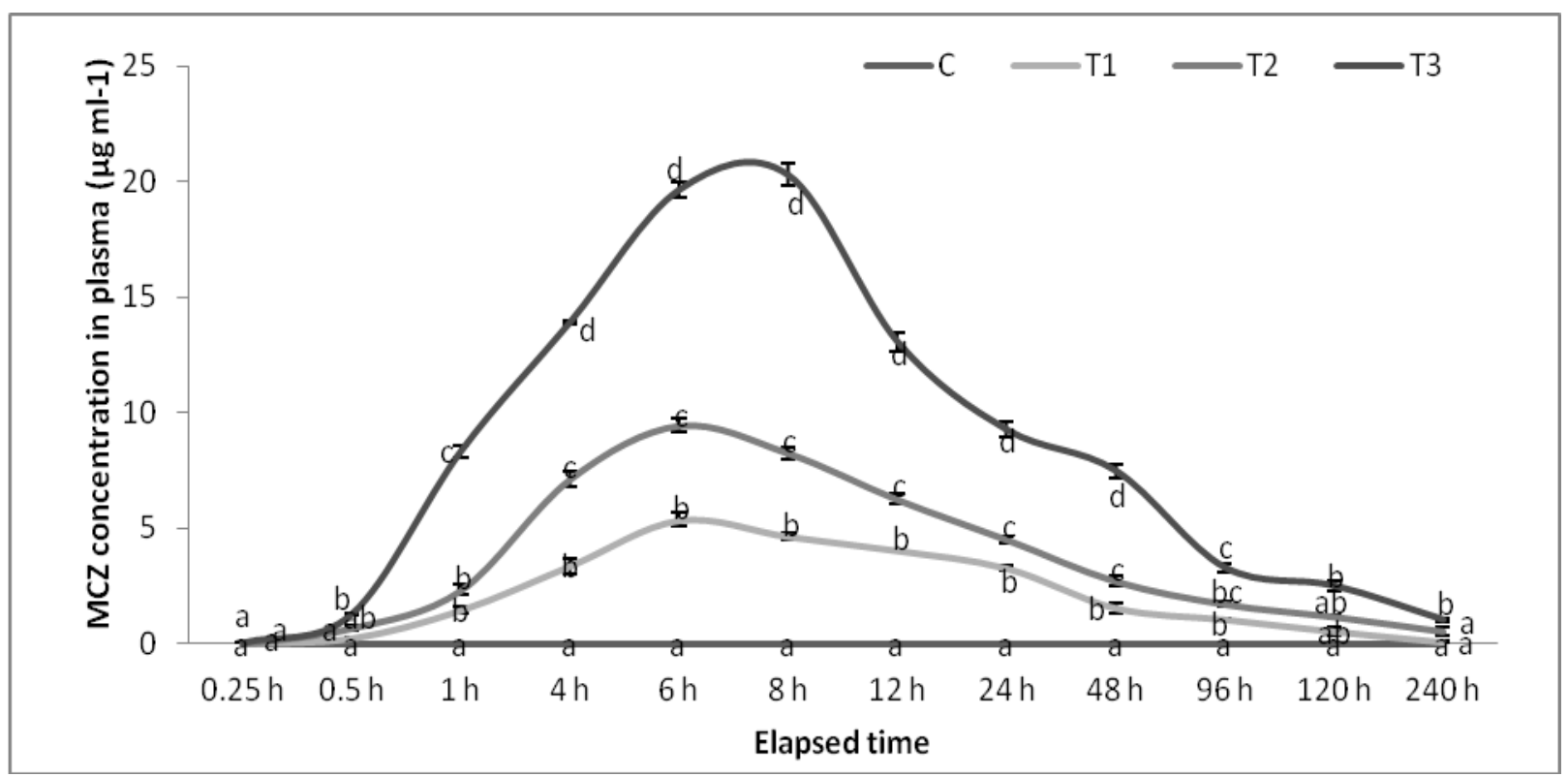

The calibration curve for a range of 0.5 to $25 \mu \mathrm{g} \mathrm{ml}^{-1}$ has shown a linear relationship with an elevated correlation coefficient indicating linearity $\left(\mathrm{R}^{2}=0.995\right)$ in fish plasma similar to the case of Puranajoti et al., (1999) reporting $\mathrm{R}^{2}$ value more than 0.99 with serum samples 
in the range of $0.5-100 \mu \mathrm{g} \mathrm{ml}^{-1} \mathrm{MCZ}$. The precision and recovery rate of MCZ was observed as varying from 0.34 to $1.97 \%$ and $88.70 \%$ to $99.03 \%$ respectively for fish plasma. In the pharmaceutical preparations the recovery percentage of $\mathrm{MCZ}$ varying from 99-102\% was reported by DeZan et al., (2009). The limit of detection and limit of quantification was $0.032 \mu \mathrm{g} \mathrm{ml}^{-1}$ and 0.109 $\mu \mathrm{gml}^{-1}$ of MCZ in plasma respectively. The low value of LOD and LOQ signifies that the HPLC condition maintained in the analysis is sensitive and sufficient to determine the quantity of MCZ in plasma and pharmaceutical samples. In the pig plasma, the LOD and LOQ of MCZ were observed to be $0.013 \mathrm{mg} \mathrm{ml}^{-1}$ and $0.044 \mathrm{mg} \mathrm{ml}^{-1}$ respectively (Barillaro et al., 2005). Hermawan et al., (2017) observed the LOD and LOQ of MCZ pharmaceutical preparations as $2.24 \mathrm{mg} \mathrm{l}^{-1}$ and $7.47 \mathrm{mg} \mathrm{l}^{-1}$, respectively and a linear calibration curve with an $\mathrm{R}^{2}$ value of 0.9983 . The experimental results demonstrated the specificity and sensitivity of the adopted methodology with good accuracy and recovery percentage. Furthermore, this procedure can be considered as convenient and quick to apply in routine analysis for the quantification of $\mathrm{MCZ}$ in fish plasma.

For assisting in early and appropriate fungal therapy of fish by MCZ medicated feed, it is crucial to understand the pharmacokinetic characteristics as they are the key treatment considerations. The variability in drug absorption is the most vital pharmacokinetic consideration that could limit the efficacy and oral availability during the initial curing phase (Lewis and Russell, 2012). Pharmacokinetics study is a mathematical model for estimating the effects and the time course of drugs inside the body. Furthermore, the pharmacokinetic properties of drugs in fisheries differ significantly between the species as well as on the mode of administration. Hence, the disposition of a drug should be inspected in the particular fish species in which it is expected to be utilized (van der Heiden et al., 1994, Kleinow et al., 1994, Martinsen et al., 1994). In the present study, we determined the plasma pharmacokinetics of $L$. rohita fed with a single dose of MCZ medicated semipurified feed. The three sub-lethal doses when incorporated orally in fish were detected in the fish plasma immediately within 30 minutes of feeding.

The $\mathrm{T}_{\max }$ value, i.e., the maximum plasma concentration-time is displayed in an hour and is defined as the time required for the drug to reach the peak plasma level after administration. It helps to estimate the rate of absorption whereas $\mathrm{C}_{\max }$ is the observed maximum concentration of drug in the plasma. Our results revealed that after onetime administration of three different sublethal doses of MCZ orally, it showed a relatively rapid absorption with the immediate detection of drug in plasma after $0.5 \mathrm{~h}$ and the $\mathrm{T}_{\max }$ value varying from 6 to $8 \mathrm{~h}$ in all the three doses. $\mathrm{C}_{\max }$ value was recorded as 5.35 $\mu \mathrm{gll}^{-1}$ and $9.44 \mu \mathrm{g} \mathrm{ml}^{-1}$ in the dose $\mathrm{T} 1$ and $\mathrm{T} 2$ respectively at the $6^{\text {th }} \mathrm{h}$ after feeding. The third and the highest sub-lethal dose of MCZ recorded peak plasma level concentration at 8 $\mathrm{h}$ after feeding as $20.28 \mu \mathrm{g} \mathrm{ml}^{-1}$. Aljaeid and Ibrahim (2016) have reported the $\mathrm{T}_{\max }$ value of $4 \mathrm{~h}$ reaching the maximum plasma concentration in albino rabbits as $13.71 \mathrm{ng} \mathrm{ml}^{-}$ ${ }^{1}$ on being fed with $150 \mathrm{mg}$ of miconazole. Cartwright (1975) has recorded human serum levels up to $1.75 \mu \mathrm{g} \mathrm{ml}^{-1}$ and $1.2 \mu \mathrm{g} \mathrm{ml}^{-1}$ on oral administration of $1.5 \mathrm{~g}$ per day and $1 \mathrm{~g}$ at $8 \mathrm{~h}$ interval of MCZ intake respectively. Boelaert et al., (1976) reported peak plasma levels reaching $0.3 \mu \mathrm{gml}^{-1}$ after single oral doses of miconazole and peak plasma levels of $6 \mu \mathrm{g} \mathrm{ml}^{-1}$ after a single intravenous dose in four hours. Studies also reported maximum MCZ plasma levels in the range of 0.5 to $1 \mu \mathrm{gml}^{-1}$ following $1 \mathrm{gm}$ of oral administration 
and $1.6 \mu \mathrm{g} \mathrm{ml} \mathrm{m}^{-1}$ on $200 \mathrm{mg}$ of intravenous injection in humans (Boelaert et al., 1976). The study conducted in pigs recorded the mean miconazole plasma peak concentrations varying from 0.10 to $0.59 \mathrm{mg} \mathrm{ml}^{-1}$ on the oral administration of $10 \mathrm{mg}$ miconazole $/ \mathrm{kg}$ body weight at 19.30 minutes (Barillaro et al., 2005). The oral administration in the form of MCZ tablets in adult humans gave a single peak concentration at $6 \mathrm{~h}$ after application with a mean value of $15.1 \mathrm{mg} \mathrm{ml}^{-1}$ and 39.1 $\mathrm{mg} \mathrm{ml}^{-1}$ for the 50 and $100 \mathrm{mg}$ doses respectively (Cardot et al., 2004). Although, the pharmacokinetic study data of azoles drugs in fish is very limited to be compared, the plasma levels in humans and the other animals shown promising results. Furthermore, there can be enormous plasma level concentration variations among the different fish species which may exist because of fish being the poikilotherms, their pharmacokinetics vary significantly depending on the mode of administration, difference in species or some other factors like alterations in water temperature and minor variations or a time lag in collecting blood samples.

The area under the curve (AUC) is a parameter used as an indicator of the drug exposure of the body and reflects the actual exposure of the drug in the body after singledose administration of the drug. The AUC value is dependent closely on the amount of drug that enters the systemic circulation and on the ability of the system to eliminate the drug (Urso et al., 2002). The AUC value was recorded to be significantly different in all the three treatment doses with the value ranging from 263.11 to $1048.99 \mu \mathrm{g}^{*} \mathrm{~h} \mathrm{ml}^{-1}$ in $\mathrm{MCZ}$ fed fish plasma. Following MCZ oral administration, the mean area under the plasma concentration curve (AUC) for miconazole was found to be $95.0 \pm 55.8$ $\mathrm{mg}^{*} \min \mathrm{ml}^{-1}$ as observed in pig plasma at the dose of $10 \mathrm{mg}$ miconazole/kg body weight
(Barillaro et al., 2005). The researchers have reported the AUC value of 231 to $294 \mathrm{ng}^{*} \mathrm{~h}$ $\mathrm{ml}^{-1}$ in albino rabbits in an in vivo drug absorption study fed with formulations composing $150 \mathrm{mg}$ of miconazole (Aljaeid and Ibrahim, 2016).

The mean residence time (MRT) of a drug is the specific time until the drug molecule is remained in the plasma before its elimination from the body and is calculated as $\mathrm{AUMC}_{0 \text { - }}$ ${ }_{\infty} / \mathrm{AUC}_{0-\infty}$. The MRT value for all the three sub-lethal doses under study was found to be significantly different $(\mathrm{p}<0.05)$ from each other varying from $52 \pm 0.13$ to $98 \pm 0.23 \mathrm{~h}$. The half-value duration (HVD) of a drug is the time at which the plasma drug concentrations were higher than half of the Cmax. HVD value of MCZ in rohu was estimated for all three doses and was recorded to be $5.53 \pm 0.02$ $\mathrm{h}, \quad 9.91 \pm 0.07 \mathrm{~h}$, and $36.71 \pm 0.05 \mathrm{~h}$ respectively. In the present study, the elimination of MCZ in rohu after three sublethal oral dosings was rapid and the elimination half-life $\left(t_{1 / 2 \beta}\right)$ was estimated to be $30 \mathrm{~h}, 71 \mathrm{~h}$ and $77 \mathrm{~h}$ respectively in plasma. The $t_{1 / 2 \beta}$ values of $51.80 \mathrm{~min}$ to $57.72 \mathrm{~min}$ were found in the plasma of sheep after IV administration by Piel et al., (1990). In healthy human plasma, MCZ was observed to have a half-life $\left(t_{1 / 2 \beta}\right)$ of about 20 to 25 hours (Lewis et al., 1976; Stevens et al., 1976). Heel et al., (1980) also confirms the elimination half-life in human plasma to be about 20 to 25 hours.

According to Daneshmend (1983), MCZ serum pharmacokinetics was observed to have a short initial half-life of less than 1 hour and a terminal half-life of 20 hours in human plasma. The rate of elimination of the drug from fish plasma is mainly influenced by the surrounding temperature (Bjorklund and Bylund, 1990). Furthermore, Chung et al., (2019) and Ellis et al., (1978) suggested that every $1^{\circ} \mathrm{C}$ change in water temperature results 
in a $10 \%$ change in the metabolic and elimination rate in the case of fish. Thus we can understand that the delayed elimination of the drug from fish and variations in the other pharmacokinetic parameters are broadly influenced by its poikilothermal behavior and can oscillate among the species depending on their surrounding environment.

In conclusion, this study exhibits that the plasma concentration of the antifungal drug MCZ in fish fed with medicated feed can be determined by a very simple assay with a good precision level. To our knowledge, the pharmacokinetic parameters of $\mathrm{MCZ}$ were evaluated for the first time in fish and the relevant data on antifungal pharmacokinetics in fish is scarce.

The result demonstrated rapid absorption and elimination of MCZ in fish plasma and the high drug plasma concentration is an excellent property from a therapeutic stance. However, due to the rapid elimination, consecutive dose administration is necessary to maintain effective concentration levels. Apart from this, taking into consideration the effect of temperature and metabolic rate, pharmacokinetic studies in the other fish species concerned should be assessed to ensure the proper utilization of the drug.

\section{Competing interests disclaimer}

Authors have declared that no competing interests exist. The products used for this research are commonly and predominantly use products in our area of research and country. There is absolutely no conflict of interest between the authors and producers of the products because we do not intend to use these products as an avenue for any litigation but for the advancement of knowledge. Also, the research was not funded by the producing company rather it was funded by personal efforts of the authors.

\section{References}

Alderman, D.J. (1985). Malachite green: a review. Journal of Fish Diseases, 8:289-298.

Aljaeid, B.M. and Ibrahim, K.M.H. (2016). Miconazole-loaded solid lipid nanoparticles: formulation and evaluation of a novel formula with high bioavailability and antifungal activity, International Journal of Nanomedicine, 11: 441-447.

Barasch, A. and Griffin, A.V. (2008). Miconazole revisited: new evidence of antifungal efficacy from laboratory and clinical trials, Future Microbiology, 3(3): 265-269.

Barillaro, V., Evrard, B., Delattre, L. and Piel, G. (2005). Oral Bioavailability in Pigs of a Miconazole/Hydroxypropyl-gcyclodextrin/ L-tartaric Acid Inclusion Complex Produced by Supercritical Carbon Dioxide Processing. The AAPS Journal, 7 (1): 149-155.

Barnes, M.E., Stephenson, H., Gabel, M. (2003). Use of hydrogen peroxide and formalin treatments during incubation of landlocked fall Chinook salmon eyed eggs. North American Journal of Aquaculture, 65:151-154.

Bjorklund, H. and Bylund, G. (1990). Temperature-related absorption and excretion of oxytetracycline in rainbow trout (Salmo gairdneri R.). Aquaculture, 84: 363-372.

Boelaert J., Daneels R., Van Landuyt H., Hospital S.J., Symoens J. (1976) Miconazole Plasma Levels in Healthy Subjects and in Patients with Impaired Renal Function. In: Williams J.D., Geddes A.M. (eds) Parasites, Fungi, and Viruses. Chemotherapy, vol 6. Springer, Boston, MA.

Bouckaert, S., Schautteet, H., Lefebvre, R., Remon, J., Van Clooster, R. (1992). Comparison of salivary miconazole 
concentrations after administration of a bioadhesive slow-release buccal tablet and an oral gel. Eur J Clin Pharmacol, 43: $137-40$.

Brugmans, J. Van Cutsem, J., Heykants, J., Schuermans, V., and Thienpont, D. (1972). Systemic Antifungal Potential, Safety, Biotransport and Transformation of Miconazole Nitrate, Europ. J. clin. Pharmacol. 5: 93-99.

Cardot, J.M. Chaumont, C., Dubray, C., Costantini, D. and Aiache, J.M. (2004). Comparison of the pharmacokinetics of miconazole after administration via a bioadhesive slow release tablet and an oral gel to healthy male and female subjects. Br J Clin Pharmacol, 58(4): 345-351.

Cardot, J.M., Jaouen, A., Godbillon, J. (1997). PKC, a new pharmacokinetic software using SAS. Eur J Pharm Biopharm, 43: 197-9.

Cartwright, R. Y. (1976). Oral clotrimazole in the treatment of fungal infection, $\mathrm{p}$. 183-187. In J. D. Williams and A. M. Geddes (ed.), Chemotherapy, vol 6. Plenum Publishing Corp., New York.

Cartwright, R. Y. J. (1975). "Anti Fungal Drugs," Journal of Antimicrobial Chemotherapy, 1(2): 141-162.

Chung, M., Trueman, C.N., Godiksen, J.A. et al., (2019). Field metabolic rates of teleost fishes are recorded in otolith carbonate. Commun Biol 2, 24.

Daneshmend T. K. \&Warnock D. W. (1983). Clinical Pharmacokinetics of Systemic Antifungal Drugs. Clinical Pharmacokinetics, 8: 7-42.

De Zan, M.M.D., Camara, M., Robles, J.C., Kergaravat, S.V. and Goicoechea, H. (2009). Development and validation of a simple stability-indicating high performance liquid chromatographic method for the determination of miconazole nitrate in bulk and cream formulations, Talanta, 79: 762-767.
Ellis, A.E., Roberts, R.J., Tytler, P. (1978). The anatomy and physiology of teleosts. In: Roberts, R.J. (Ed.), Fish Physiology. Balliere Tindall, London, pp. 13-54.

Forneris, G., Bellardi, S., Palmegiano, G.B., Saroglia, M., Sicuro, B., Gasco, L., Zoccarato, I. (2003). The use of ozone in trout hatchery to reduce saprolegniasis incidence. Aquaculture 221:157-166.

Godefroi, E. F., Heeres, J., Van Cutsem, J., and Janssen, P. A. J. (1969). The preparation and antimycotic properties of derivatives of 1-phenethylimidazole, J Med Chem, 12:781.

Heel, R.C. Brogden, R.N. Pakes, G.E. Speight T.M. and Avery GS. (1980). Miconazole - A Preliminary Review of its Therapeutic Efficacy in Systemic Fungal Infections. Drugs 19: 7-30

Hermawan, D., Suwandri, Sulaeman, U., Istiqomah, A. and Aboul-Enein, H.Y. (2017). Development of high performance liquid chromatography method for miconazole analysis in powder sample, Materials Science and Engineering, 172: 012011.

Hosotsubo, H. (1988). Quantitative Determination of Miconazole in Human Serum by High- Performance Liquid Chromatography, Chromatographia, 25(8): 717-720.

Hu, Y., Shen, Y., Tu, X., Wu, X., Wang, G., Ling, F. (2019). Isolation of antiSaprolegnia lignans from Magnolia officinalis and SAR evaluation of honokiol/magnolol analogs, Bioorganic and Medicinal Chemistry Letters, 29( 3): 389-395.

International Conference on Harmonization (ICH) of Technical Requirements for Registration of Pharmaceuticals for Human Use (2005). Validation of Analytical Procedures: Text and Methodology, ICH Steering Committee: Geneva. Methodology, ICH Steering 
Committee: Geneva.

Kleinow, K.M., Jarboe, H.H., Shoemaker, K.E. (1994), Comparative pharmacokinetics and bioavailability of oxolinic acid in channel catfish (Ictalurus punctatus) and rainbow trout (Oncorhynchus mykiss) Can. J. Fish Aquat. Sci., 51: 1205-1211.

Lewi, P.J. Boelaert, J., Daneels, R., De Meyere, R., Van Landuyt, H., Heykants, U.P., Symoens, J. and Wynanls, (1976). Pharmacokinetic profile of intravenous miconazole in man: Comparison of normal subjects and patients with renal insufficiency. European Journal of Clinical Pharmacology, 10: 49.

Lewis and Russell, E. (2012). Importance of Pharmacokinetic Considerations for Selecting Therapy in the Treatment of Invasive Fungal Infections, American Journal of Therapeutics, 19(1): 51-63.

Martinsen, B., Horsberg, T.E., Ingebrigtsen, K., Gross, I.L. (1994), Disposition of ${ }^{14} \mathrm{C}$-sarafloxacin in Atlantic salmon (Salmo salar), rainbow trout (Oncorhynchus mykiss), cod (Gadus morhua) and turbot (Scophthalmus maximus) as demonstrated by means of whole-body autoradiography and liquid scintillation counting, Dis. Aquat. Org., 18: 37-4.

Moriello, K. A., Coyner, K. Paterson, S., Mignon B. (2017). Diagnosis and treatment of dermatophytosis in dogs and cats. Veterinary Dermatology, 28(3): 208-303.

Olah J, Farkas J. (1978). Effect of temperature, $\mathrm{pH}$, antibiotics, formalin and malachite green on the growth and survival of Saprolegnia and Achlya parastic on fish. Aquaculture, 13:273288.

Phillips, A.J., Anderson, V.L., Robertson, E.J., Secombes, C.J., Van West, P. (2008). New insights into animal pathogenic oomycetes. Trends in
Microbiology, 16:13-19.

Piel, G., Evrard, B., Van Hees, T., Delattre L. (1999) Comparison of the IV pharmacokinetics in sheep of miconazole-cyclodextrin solutions and a micellar solution. International Journal of Pharmaceutics, 180: 41-45.

Pottinger, T.G., Day, J.G. (1999). A Saprolegnia parasitica challenge system for rainbow trout: assessment of Pyceze as an anti-fungal agent for both fish and ova. Diseases of Aquatic Organisms, 36:129-141.

Puranajoti, P., Kasina, R. and Tenjarla S. (1999). Microbiological and HPLC analysis of miconazole in skin, serum and phase-solubility studies Journal of Clinical Pharmacy and Therapeutics, 24: 445-450.

Rach, J.J., Redman, S., Bast, D., Gaikowski, M.P. (2005). Efficacy of hydrogen peroxide versus formalin treatments to control mortality associated with saprolegniasis on lake trout eggs. North American Journal of Aquaculture, 67:148-154.

Robert A. and Fromtling (1988). Overview of Medically Important Antifungal Azole Derivatives. Clinical Microbiology Reviews, 1(2): 187-217.

Sarowar, M. N., Van Den Berg, A. H., McLaggan, D., Young, M. R., and Van West, P. (2013). Saprolegnia strains isolated from river insects and amphipods are broad spectrum pathogens. Fungal Biology, 117(11-12), 752-763.

Sawyer, P.R., Brogden, R.N., Pinder, R.M., Speight, T.M., Avery, G.S. (1975). Miconazole: a review of its antifungal activity and therapeutic efficacy. Drugs, 9: 406-23.

Singh, M., Saha, R. K., Saha, H., Sahoo, A. K., and Biswal, A. (2018)a. Effects of sub- lethal doses of miconazole nitrate on Labeo rohita and its curing efficacy 
against Saprolegniasis. Aquaculture, 495: 205-213.

Singh, M., Saha, R.K., Saha, H., Parhi, J. (2018)b. Effect of miconazole nitrate on immunological response and its preventive efficacy in Labeo rohita fingerlings against oomycetes Saprolegnia parasitica. J. Fish Dis., 41:1539-1548.

Song, J., Han, G., Wang, Y.et al., (2020). Pathway and kinetics of malachite green biodegradation by Pseudomonas veronii. Sci Rep 10, 4502.

Srivastava, G.C. and Srivastava, R.C. (1978). A note on the potential applicability of malachite green oxalate in combating fish-mycoses. Mycopathologia, 64:169171.

Srivastava, S., Sinha, R., Roy, D. (2004). Toxicological effects of malachite green. Aquatic Toxicology, 66:319-329.

Stammati, A., Nebbia, C., De Angelis, I., Albo, A.G., Carletti, M., Rebecchi, C., Dacasto, M. (2005). Effects of malachite green (MG) and its major metabolite, leuco-malachite green (LMG), in two human cell lines. Toxicology in vitro, 19:853-858.

Stevens. D.A. Levine. M.B. and Deresinski. S.C. (1976). Miconazole in coccidioidomycosis. II. Therapeutic and pharmacologic studies in man. American Journal of Medicine, 60: 191.
Straus, D.L., Farmer, B.D., Ledbetter, C.K., Beck, B.H., Williams, R.S., Clark, M.L., Freeze, T.M. (2016). Use of copper sulfate to control egg saprolegniasis at a commercial sunshine bass hatchery. North American Journal of Aquaculture, 78:243-250.

Urso, R., Blardi, P. et al., (2002). A short introduction to pharmacokinetics. European Review for Medical and Pharmacological Sciences 6: 33-44.

Van Cutsem, J.M. and Thienpont, D. (1972). Miconazole, a broad-spectrum antimycotic agent with antibacterial activity. Chemotherapy, 17(6):392-404.

Van der Heijden, M.H.T., Keukens, H.J., van den Nieuwboer, W.H.F.X., Mengelers, M.J.B., and Boon, J.H. (1994). Plasma disposition of flumequine in common carp (Cyprinus carpio L., 1758), African catfish (Clarias gariepinus Burchell, 1822) and European eel (Anguilla anguilla L., 1758) after a single per oral administration Aquaculture, 123: 21-30.

vanWest, P. (2006). Saprolegnia parasitica, an oomycete pathogen with a fishy appetite: new challenges for an old problem. Mycologist, 20(3), 99-104.

Vazquez, J.A. and J.D. Sobel (2012) Miconazole mucoadhesive tablets: A novel delivery system, Clin. Infect.Dis. 54: 1480-4.

\section{How to cite this article:}

Mukta Singh, Himadri Saha and Ratan Kumar Saha. 2020. Comparative Pharmacokinetics of the Orally Administered Sub-lethal Doses of Miconazole Nitrate in Labeo rohita. Int.J.Curr.Microbiol.App.Sci. 9(12): 3197-3210. doi: https://doi.org/10.20546/ijcmas.2020.912.381 